is hoped to publish, as also an account of the geology of the neighbourhood of Cairo and other papers.

W. F. Hune.

\title{
Frederick T. Maidwell, F.G.S.
}

Born 26Th March, 1872.

Died lst May, 1921.

WE regret to announce the death of Mr. Frederick T. Maidwell, F.G.S., which took place suddenly on 1st May, at Runcorn, in his fiftieth year. He was born in 1872 at Gunnerside, in Swaledale, and a few months after his birth his parents removed to Coventry, where his father held the position of head master of St. Mark's New School until his death in 1882 . The following years were full of difficulty and struggle, but after a short time spent in teaching at his father's old school, and later at the Bablake Secondary School, Coventry, he became interested in handicraft subjects, and qualified as an instructor. He held positions at Wolverhampton and Dudley, and finally in 1908 removed to Runcorn on accepting an appointment under the Education Authority there, which he retained until his death. He rendered useful service to the town in many ways, serving on the Free Library Committee, and also taking a very active interest in the local volunteer movement during the period of the war. Geology claimed a great portion of his leisure, and while in the Midlands he was an ardent member of the Warwickshire Naturalists' and Archæologists' Field Club, and several of his early papers are printed in its proceedings. He was indefatigable in observing and recording particulars of sections, old and new, in the Liverpool district, and published several papers in the Proceedings of the Liverpool Geological Society, of which he was a valued member, most of them relăting to the Triassic strata of Cheshire. He also devoted some time to the study of the fossil footprints of the Trias, the results of which he recorded in two of his most important communications, in which he gave very careful descriptions of a number of Rhynchosauroir types, including webbed forms. His death removes an earnest. patient, and painstaking worker, greatly esteemed by all who knew him. He leaves a widow and three children.

T. A, J 